Reprod. Nutr. Dévelop., 1986, 26 (4), 969-985.

\title{
Dietary $\alpha$-linolenic acid deficiency in the rat. I. Effects on reproduction and postnatal growth
}

\author{
Ph. GUESNET, G. PASCAL $\left({ }^{*}\right)$, G. DURAND \\ Station de Recherches de Nutrition. \\ (*) Laboratoire des Sciences de la Consommation, \\ I.N.R.A. 78350 Jouy-en-Josas, France.
}

Summary. The effects of a dietary $\alpha$-linolenic acid (18:3n-3) deficiency on reproduction and postnatal growth in rats were studied during 3 successive gestations and 4 successive generations. Female rats received respectively a semi-synthetic diet in which the lipids were incorporated either as sunflower oil at $1.5 \%$ (deficient diet) or as soya oil at $1.87 \%$ (control diet).

Both diets supplied the same amount of linoleic acid (18:2 n-6) $(940 \mathrm{mg} / 100 \mathrm{~g}$ of diet), but the sunflower oil supplied 22 times less $\alpha$-linolenic acid than the soya diet $(6 \mathrm{mg}$ vs $130 \mathrm{mg} / 100 \mathrm{~g}$ of diet).

The results showed that, in our experimental conditions, the $\alpha$-linolenic acid deficiency had no effect on fecundity (\% of pregnant females), fertility (number of pups/litter), pup birth weight, food intake and weight of pregnant or lactating females, or pup growth during suckling.

However, this deficiency did cause abnormally high rates of perinatal mortality from birth to postpartum day 3 , namely on the average, for successive gestations : $18.5 \%$ in deficient pups vs $5.2 \%$ in the controls, and for successive generations : $16.6 \%$ in deficient pups vs $5.3 \%$ in the controls.

Rat n-3 PUFA requirement during reproduction has been discussed; it appears to be more than $100 \mathrm{mg} / 100 \mathrm{~g}$ of feed. But this need should also be estimated in relation to $\mathrm{n}-6$ PUFA supply; for female rats during reproduction, the ratio $n-6: n-3$ should be less than 10.

\section{Introduction.}

When demonstrating the essentiality of polyunsaturated fatty acids (PUFA) in reproduction and growth, Burr and Burr (1930) did not distinguish between the $n-6$ and $n-3$ fatty acid series. Since then, various authors have shown the essentiality of linoleic acid and its long-chain derivatives (n-6 PUFA) in ensuring growth, reproduction, and lactation (McKenzie et al., 1939), viability of the young (Quackenbush et al., 1942) and skin integrity (Mohrhauer and Holman, 1963) in all land mammals. They also demonstrated that $\alpha$-linolenic acid could not totally supply the linoleic acid for these functions (McKenzie et al., 1939 ; Quackenbush et al., 1942 ; Kummerow et al., 1952 ; Mohrhauer and Holman, 1963 ; Jorgensen 
and Holmer, 1969), and this led them, in fact, to disavow its essentiality and even its utility.

But the methodology used by these various authors was based on an incorrect concept, which was to use the same criteria to judge the properties of two different agents, although there was nothing to indicate that those agents had the same functions. As Crawford and Sinclair (1972) so justly remarked, it was like judging the essentiality of an amino acid (for example, phenylalanine) by assuming that it could remove the symptoms of another amino acid deficiency (for example, tryptophane). However, more recent results recalled to mind $\alpha$-linolenic acid and its derivatives. The data of Lee et al. (1967) showed the exclusive essentiality of n-3 PUFA in trout. Shortly afterwards, these fatty acids were shown to be abundant in the phospholipids of mammalian neural structures $(e . g$. brain, retina) (Svennerholm, 1968 ; Sinclair and Crawford, 1972 ; Breckenridge et al., 1973 ; Farnsworth et al., 1979).

It was also proved that n-3 PUFA were precursors of endoperoxides (e.g. prostaglandins, prostacyclins, thromboxanes) from eicosapentaenoic acid (20:5 n-3) (Van Dorp et al., 1964) as n-6 PUFA from arachidonic acid (20: 4 n-6).

After the first suggestions of Dyerberg et al. (1978) in this matter, Needleman et al. (1979) reported that, of the eicosanoids from the $n-3$ series, $\mathrm{PGl}_{3}$ was antiaggregating like its homologue of the $n-6 \mathrm{PGI}_{2}$ series, but that $T X A_{3}$, contrary to its homologue in the n-6 TXA $A_{2}$ series, showed very little capacity in this respect. In this order of ideas, the anti-aggregating properties of fish oils, rich in $20: 5 \mathrm{n}$ 3, were confirmed in humans (Siess et al., 1980 ; Sinclair, 1981). Moreover, Budowski et al. (1980) showed that $\alpha$-linolenic acid (18: 3 n-3) prevented nutritional encephalomalacia in chickens ; according to these authors, the sparing effect would be due to competitive inhibition of the conversion of linoleic acid into arachidonic acid by $\alpha$-linolenic acid (Holman, 1964 ; Brenner and Peluffo, 1966). This inhibition, by displacing the balance between $T X A_{2}$ and $T X A_{3}$ and enhancing the latter, would avoid the formation of thrombi in the blood vessels of the brain.

It has also been shown that a n-3 PUFA-deficient diet in rats increased the rate of neonatal mortality (Sinclair and Crawford, 1973 ; François et al., 1980), impaired learning ability (Galli et al., 1975 ; Lamptey and Walker, 1978 ; François, 1983), caused disorders in vision physiology (Wheeler et al., 1975 ; François, 1983 ; Nouvelot et al., 1985) and modified some membrane enzyme activities which could alter membrane physiology (Bernsohn and Spitz, 1974 ; Sun and Sun, 1974 ; McMurchie and Raison, 1979).

In monkeys, it was observed that the addition of linseed oil, rich in $\alpha$-linolenic acid, diminished physiopathological symptoms occurring when the dietary lipids contained only corn oil, rich in linoleic acid but poor in $\alpha$-linolenic acid (Fiennes et al., 1973). Moreover, deprivation of dietary $n-3$ fatty acids during gestation and infancy caused visual impairment in infant rhesus monkeys (Neuringer et al., 1984).

In humans, the neurological disorders in a 6-year old girl, maintained by total parenteral nutrition, disappeared when $18: 3 \mathrm{n}-3$ was added into a nutritive preparation that had previously contained $18: 2 n-6$ as the only PUFA (Holman 
et al., 1982). These authors estimated that the $\alpha$-linolenic acid requirement was about $0.54 \%$ of the calories.

Although viewed favourably at present (Lemarchal, 1978; Rivers and Frankel, 1981 ; Tinoco, 1982), the essential function of $n-3$ PUFA is still controverted, especially as concerns reproduction and growth (Tinoco et al., 1971 ; Alling et al., 1974).

The aim of the present study was to supply decisive material to answer this question by investigating the effects of a diet with a low $\alpha$-linolenic acid content on reproduction and postnatal growth in rats over successive gestations and generations.

\section{Material and methods.}

From weaning at 21 days and until they were 8 weeks old, 100 female Wistar rats were given a balanced semi-synthetic diet in which the lipids were supplied exclusively by $1.5 \%$ sunflower oil (table 1 ). The casein used was defatted and contained only a negligible amount of other fatty acids which did not modify appreciably either the proportion or the fatty acid composition of the dietary lipids. For $100 \mathrm{~g}$, such a diet supplied about $940 \mathrm{mg}$ of $\mathrm{n}-6$ fatty acid (18:2 n-6) but only $6 \mathrm{mg}$ of $\alpha$-linolenic acid (18: $3 \mathrm{n}-3$ ).

When the females were 8 weeks old ( 2 weeks before mating), they were divided into two equal groups. One group continued to receive the sunflower oil diet low in $\alpha$-linolenic acid, while the other group was given the same diet in which the sunflower oil was replaced by $1.87 \%$ of soya oil. For $100 \mathrm{~g}$, the soya oil diet contained $936 \mathrm{mg}$ of linoleic acid and $130 \mathrm{mg}$ of $\alpha$-linolenic-acid. The soya oil used was not heated during extraction-purification and contained only traces of trans $18: 3$ n-3 acid.

TABLE 1

Diet composition (per $\mathrm{kg}$ ).

\begin{tabular}{|c|c|c|}
\hline & $\begin{array}{c}\text { Soya oil (S) } \\
\text { diet }\end{array}$ & $\begin{array}{c}\text { Sunflower oil (T) } \\
\text { diet }\end{array}$ \\
\hline Casein (1) & 220 & 220 \\
\hline DL Methionine ( $\left.{ }^{1}\right)$ & 1.6 & 1.6 \\
\hline Cellulose (1) ..... & 20 & 20 \\
\hline Starch (1) .. & 459.7 & 463.4 \\
\hline Saccharose (1) & 230 & 230 \\
\hline $\mathrm{Oi} \ldots \ldots \ldots \ldots$ & 18.7 & 15.0 \\
\hline Vitamin mixture (i) (1) $\ldots \ldots \ldots \ldots \ldots \ldots \ldots \ldots \ldots \ldots$ & 10 & 10 \\
\hline Mineral mixture ${ }^{2}$ ) & 40 & 40 \\
\hline
\end{tabular}

(1) United States Biochemical Corp., Cleveland (USA). The vitamin mixture used is the vitamin diet for fortification mixture.

(2) Composition of the mineral mixture/100 g: $\mathrm{CaHPO}_{4}, 2 \mathrm{H}_{2} \mathrm{O}, 38.0 ; \mathrm{K}_{2} \mathrm{HPO}_{4}, 24.0 ; \mathrm{CaCO}_{3}$, $18.1 ; \mathrm{NaCl}, 7.0 ; \mathrm{MgO}, 2.0 ; \mathrm{MgSO}_{4}, 7 \mathrm{H}_{2} \mathrm{O}, 9.0 ; \mathrm{FeSO}_{4}, 7 \mathrm{H}_{2} \mathrm{O}, 0.7 ; \mathrm{ZnSO}_{4}, \mathrm{H}_{2} \mathrm{O}, 0.5 ; \mathrm{MnSO}_{4}, \mathrm{H}_{2} \mathrm{O}$, $0.5 ; \mathrm{CuSO}_{4}, 5 \mathrm{H}_{2} \mathrm{O}, 0.1 ; \mathrm{NaF}, 0.1 ; \mathrm{Al}_{2}\left(\mathrm{SO}_{4}\right)_{3} \mathrm{~K}_{2} \mathrm{SO}_{4}, 24 \mathrm{H}_{2} \mathrm{O}, 0.02 ; \mathrm{KI}, 0.008 ; \mathrm{CoCO}_{3}, 0.008$; $\mathrm{Na}_{2} \mathrm{SeO}_{3}, 5 \mathrm{H}_{2} \mathrm{O}, 0.001$. 
Thus, at equal dietary intakes, the female rats of the sunflower oil group ingested as much linoleic acid as the rats given the soya oil diet but 22 times less $\alpha$-linolenic acid (table 2).

In these 100 female rats, called F0, and in their progeny we studied the effects of $\alpha$-linolenic deficiency on reproduction using two experimental designs.

Design / carried out over 3 successive gestations (FO $\rightarrow \mathrm{F} 1$; FO $\rightarrow \mathrm{F}^{\prime}$; ; FO $\rightarrow$ F $1^{\prime \prime}$ ). - The female FO rats of each group were mated at 10 weeks of age. After raising their litter for 3 weeks, they were mated again at 18 weeks. Those which had a second litter were mated a third time at 26 weeks. We thus obtained the litters (F1, F1', F1") of 3 consecutive gestations.

Design /I carried out over 4 successive generations (F0 $\rightarrow$ F1 ; F1 $\rightarrow$ F2 ; F2 $\rightarrow$ F3 ; F3 $\rightarrow$ F4). - In each generation, 40 to 50 females of the sunflower oil lineage were divided into two groups at 8 weeks of age, that is, 2 weeks before mating. One group continued to receive the sunflower oil diet, while the other was given the soya oil diet. These females were then mated at 10 weeks of age.

In the overall study, the females were left with males for one sexual cycle (4 days). The males were stock-breeding rats, receiving a commercial diet. Twenty

TABLE 2

Fatty acid composition of dietary lipids.

\begin{tabular}{|c|c|c|}
\hline \multirow[b]{2}{*}{ Fatty acids } & \multicolumn{2}{|c|}{ Diet } \\
\hline & Soya oil (S) & Sunflower oil (T) \\
\hline $\begin{array}{l}\text { C14:0 } \\
\text { C16:0 } \\
\text { C17 : } 0 \\
\text { C18 : } 0 \\
\text { C20 : } 0 \\
\text { C22 : } 0\end{array}$ & $\begin{array}{r}0.3 \\
10.1 \\
0.2 \\
5.6 \\
0.4 \\
0.5\end{array}$ & $\begin{array}{r}0.3 \\
6.4 \\
\operatorname{tr}\left(^{*}\right) \\
3.9 \\
0.3 \\
0.7\end{array}$ \\
\hline$\Sigma$ saturated & 17.2 & 11.6 \\
\hline $\begin{array}{l}\text { C16: }: 1 \\
\text { C18 }: 1 \\
\text { C20 }: 1\end{array}$ & $\begin{array}{r}\operatorname{tr}(*) \\
21.4 \\
0.3\end{array}$ & $\begin{array}{r}0.2 \\
21.4 \\
0.2\end{array}$ \\
\hline$\Sigma$ monounsaturated & 21.7 & 21.6 \\
\hline C18: $2 n-6$ & 53.5 & 66.4 \\
\hline$C 18: 3 n-3$ & 7.4 & 0.4 \\
\hline $\begin{array}{l}\text { Fatty acids } / 100 \mathrm{~g} \text { of diet : } \\
\text { C18:2n-6 (mg) } \\
\text { C18 }: 3 \mathrm{n}-3(\mathrm{mg})\end{array}$ & $\begin{array}{l}940.0 \\
130.0\end{array}$ & $\begin{array}{r}936.0 \\
6.0\end{array}$ \\
\hline$n-6 / n-3$ & 7.2 & 166.7 \\
\hline
\end{tabular}

${ }^{*}$ ) $\operatorname{tr}=$ traces. Dietary lipid fatty acid composition was analysed by gas chromatography of fatty acid methyl esters in the following conditions: Packard model 427 chromatograph : glass capillary column ; stationary phase FFAP ; carrier gas pressure $\mathrm{H}_{2}: 0.6$ bar ; temperature : $190^{\circ} \mathrm{C}$; detection by flame ionization. 
days later, the pregnant animals were put into individual cages. Immediately after parturition, each dam and its litter, including eventual stillborns, were weighed; litter size was determined.

On postpartum day 3 , the litters were equalized to 10 pups each, except in the F1" and F4 generations in which the litters could not be equalized to more than 7 or 8 pups each, respectively. The dams and their litters were weighed separately every day until weaning at 21 days. The number of pups was checked every day.

After we were sure that the dietary intake of the females during gestation was independent of the diet given, we measured the daily intake of 10 of them per group from day of parturition to day 18 of lactation; beyond that time, it was impossible to measure intake because the pups inevitably ate of the dam's feed.

Twelve 3-day old pups and twelve 21-day old ones were sacrificed from the young of each gestation and each generation. In each generation, 6 dams were also sacrificed at the end of lactation as well as 6 non-pregnant females of the same age. The stomach content of each 3-day old pup was collected and pooled; the lipids of the so obtained pool were extracted and their fatty acid composition analysed by gas-liquid chromatography on capillary glass column.

The blood of all the sacrificed animals of the same lot was collected, pooled and centrifuged after coagulation. The brain, eyes, liver, heart were also rapidly sampled, weighed and pooled. The serum and organs were lyophilised and then stored at $-80^{\circ} \mathrm{C}$.

The empty carcass of each pup was weighed, ground under liquid nitrogen, and also lyophilised and stored at $-80^{\circ} \mathrm{C}$. The composition of theses different lipid fractions will be published later.

\section{Results.}

Reproduction (tables 3, 4).

Fecundity rate (number of pregnant females \% of females mated) (table 3). - The fecundity rate (about $55 \%$ ) at the different stages was independent of the diet. It was different in " soya » and " sunflower" females only at stage F3 in which it did not exceed $32 \%$ in the latter and remained within the average $55 \%$ in the former. However, independently of any dietary effect, the fecundity rate was markedly higher (65\% or more) than the mean at stage $\mathrm{FO}^{\prime}$, which corresponded to the second gestation of F0 dams.

Fertility (number of pups per litter) (table 4). - The number of pups per litter was not affected by diet, except at stages F3 and F4 where the number was markedly higher in litters from "sunflower " dams than in those from "soya " dams ( 13 and $17 \%$, respectively). However, considering the wide dispersion of the data, the deviations were not statistically significant.

According to design I, the fertility rate was maximal at the second gestation (stage $\mathrm{FO}^{\prime}$ ) with a mean litter of 13 or more young. 
TABLE 3

Fecundity : effects of an $\alpha$-linolenic acid-deficient diet on fecundity over successive gestations or successive generations.

\begin{tabular}{|c|c|c|c|c|c|c|c|c|}
\hline & \multicolumn{4}{|c|}{ Successive gestations } & \multicolumn{4}{|c|}{ Successive generations } \\
\hline & & Fo & $\mathrm{FO}^{\prime}$ & Fo" & Fo & $\mathrm{F} 1$ & $\mathrm{~F} 2$ & F3 \\
\hline Gestation number & & 1 & 2 & 3 & 1 & 1 & 1 & 1 \\
\hline Number of mated females (mF) & $\begin{array}{l}\mathrm{S} \\
\mathrm{T}\end{array}$ & $\begin{array}{l}51 \\
52\end{array}$ & $\begin{array}{l}24 \\
23\end{array}$ & $\begin{array}{l}16 \\
15\end{array}$ & $\begin{array}{l}51 \\
52\end{array}$ & $\begin{array}{l}24 \\
24\end{array}$ & $\begin{array}{l}23 \\
23\end{array}$ & $\begin{array}{l}22 \\
22\end{array}$ \\
\hline Number of pregnant females $(\mathrm{pF})$ & $\begin{array}{l}\mathrm{S} \\
\mathrm{T}\end{array}$ & $\begin{array}{l}27 \\
28\end{array}$ & $\begin{array}{l}16 \\
15\end{array}$ & $\begin{array}{l}9 \\
8\end{array}$ & $\begin{array}{l}27 \\
28\end{array}$ & $\begin{array}{l}13 \\
15\end{array}$ & $\begin{array}{l}13 \\
13\end{array}$ & $\begin{array}{r}12 \\
7\end{array}$ \\
\hline Fecundity rate $(\mathrm{mF} \% \mathrm{pF})$ & $\begin{array}{l}S \\
T\end{array}$ & $\begin{array}{l}53 \\
54\end{array}$ & $\begin{array}{l}67 \\
65\end{array}$ & $\begin{array}{l}56 \\
53\end{array}$ & $\begin{array}{l}53 \\
54\end{array}$ & $\begin{array}{l}54 \\
63\end{array}$ & $\begin{array}{l}57 \\
57\end{array}$ & $\begin{array}{l}55 \\
32\end{array}$ \\
\hline
\end{tabular}

$\mathrm{S}=$ Soya oil ; $\mathrm{T}=$ Sunflower oil.

Pup birth weight (table 4). - There was no significant difference in pup birth weight which was about $6.1 \mathrm{~g}$. We just observed that the weight of the "soya" animals rose slightly over successive generations, bringing the mean weight from $5.9 \mathrm{~g}$ in the $\mathrm{F} 1$ generation pups to $6.5 \mathrm{~g}$ in the $\mathrm{F} 4$ generation.

Litter birth weight (table 4). - According to design I, diet had no effect on litter birth weight. Only the second gestation litters of each group showed a markedly higher weight than the mean because there were more pups per litter, as mentioned above.

According to design II, the litters of F2 and F3 "sunflower " dams were significantly heavier $(P<0.05)$ than those of the "soya " dams; this was due to the higher fertility of the former animals.

Perinatal mortality (table 4).

a) Stillbirth rate. - The stillbirth rate (pups born dead and/or which died during expulsion \% of the litter) was considerably higher in " sunflower " dams, where it varied from $7.5 \%$ (F1) to $16 \%$ ( $F 1$ "), than in " soya " dams where it never again exceeded $5.8 \%$ in the worst case (F4).

In " sunflower " litters, the stillbirth rate increased with successive gestations (design 1), while it reached a plateau at stage F3 in the successive generations (design II). However, according to design $I$, dam age at the third gestation $\left(F_{0}\right)$ should be taken into account since the stillbirth rate also increased at that stage and in the same proportion in relation to $F 1(\times 2)$ in " soya " dams. At the same stage, the means of each dietary group were always significantly different.

b) Postpartum mortality. - There was no mortality after postpartum day 3 with either of the diets used. In " soya " animals, it did not exceed $2.9 \%$ $(\mathrm{F} 1, \mathrm{~F} 1$ ") but in " sunflower " animals, it was never less than $4.8 \%$ (F3) and reached almost $8 \%$ in F1". In our experimental conditions, postpartum mortality was not affected by dam age.

As for stillbirth rate, a comparison of the different diets showed that the mean postpartum mortality at a given stage were always significantly different. 


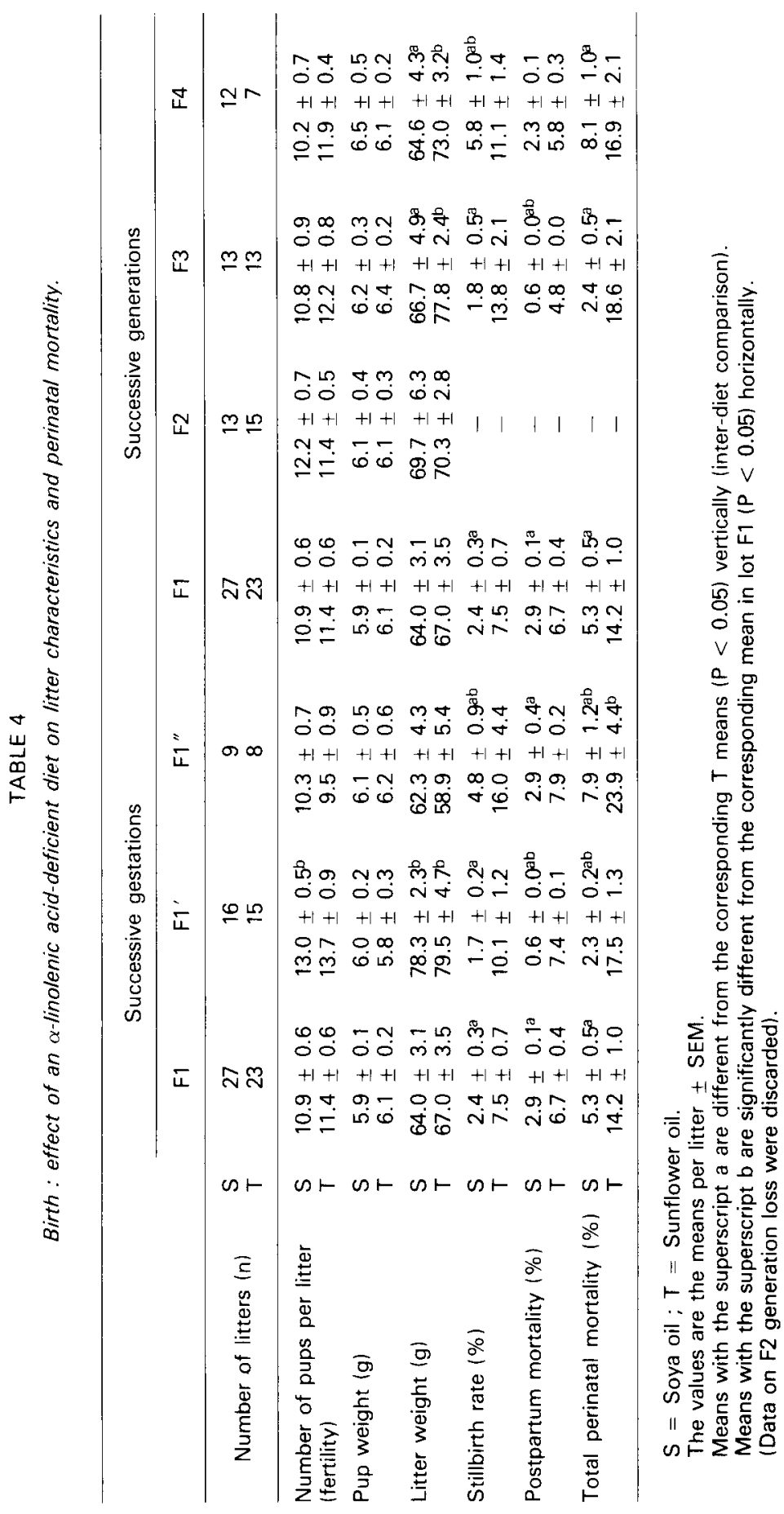




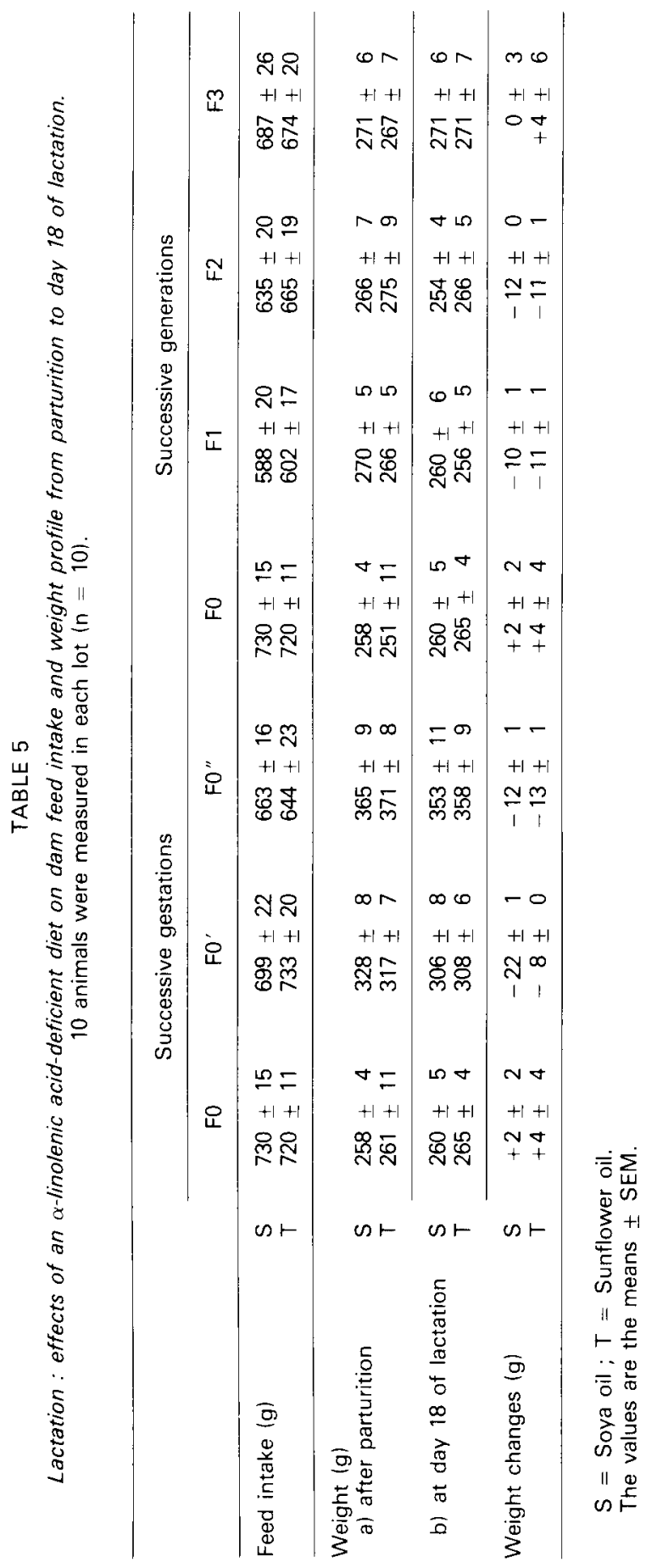




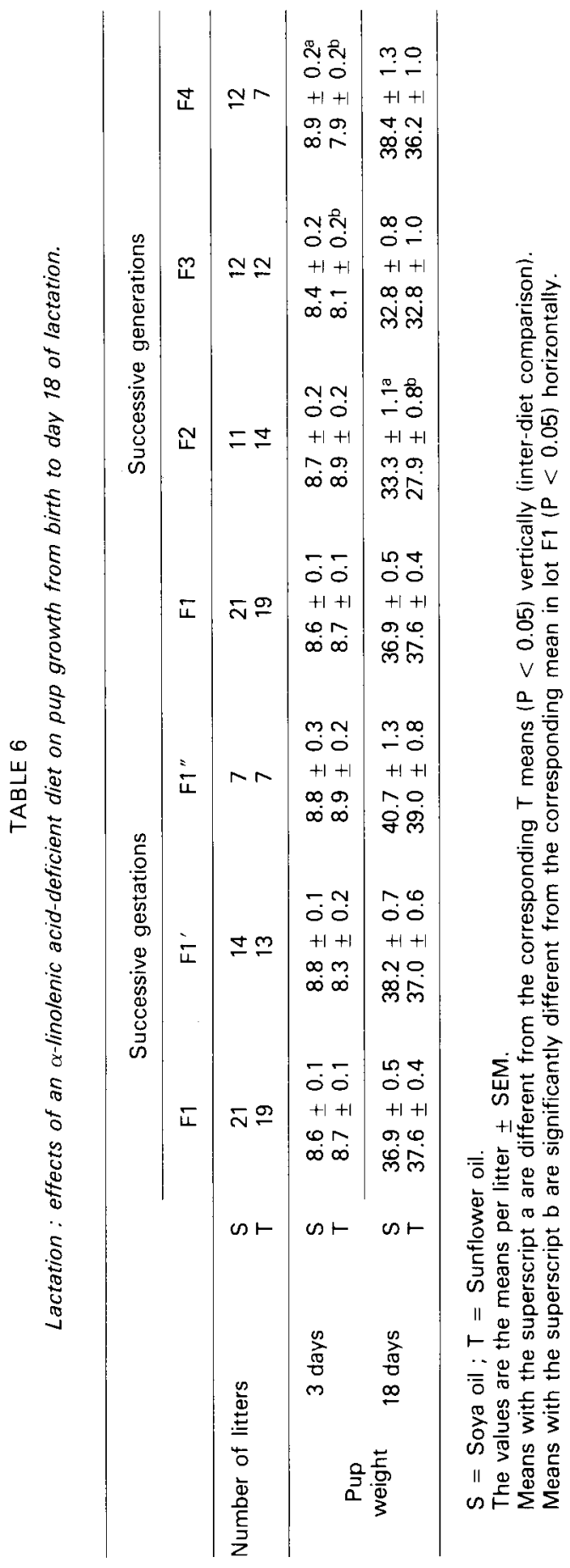


c) Total perinatal mortality. - Total perinatal mortality, which was never more than $8.1 \%$ in "soya " animals, varied between 14 (F1) and $24 \%$ (F1") in " sunflower " rats. While this rate seemed to increase with successive gestations, particularly at the end of the third gestation (design I), it hardly exceeded the level that was already reached in the first generation in design II.

In " sunflower " rats, stillbirth represented from 53 to $75 \%$ of the total perinatal mortality. In " soya " rats, it was 45 to $75 \%$. Thus, stillbirth was the predominant cause of perinatal mortality.

Lactation (tables 5, 6).

Dietary intake and dam weight changes during lactation (table 5). - The dietary intake of the lactating dams during the 18-day period studied was about $670 \mathrm{~g}$; it varied widely from one gestation or generation to the next, but was always independent of the diet.

At the end of 18 days, dam weight sometimes increased slightly (F0, F3), but more often it declined a little. These positive or negative variations never exceeded $7 \%$ of the initial weight and were never significant.

Pup growth (table 6). - The weight of 3-day old pups was independent of the diet, except in the F4 generation in which "sunflower " pups weighed significantly less than their "soya " counterparts $(7.9 \mathrm{vs} 8.9 \mathrm{~g})$. While " soya " pups showed no significant changes in weight at any gestation or generation, the weight of the "sunflower " pups of the F3 and F4 generations was less than that of the $F 1$ and $F 2$ generations. This was probably because there were more pups in the $F 3$ and F4 litters.

At 18 days of age, only the $\mathrm{F} 2$ generation of " sunflower » pups weighed less than their " soya " counterparts, although there was no difference between them at 3 days of age. However, the weight difference observed at 3 days between F4 generation pups was no longer found at 18 days because the litters were equalized.

Finally, the few punctual disparities occurring could not be due to a systematic mechanism, and $\alpha$-linolenic acid deficiency appeared to have no effect on pup growth during suckling.

\section{Discussion.}

\section{Gestation and parturition.}

Our data show that an $\alpha$-linolenic acid deficiency $(6 \mathrm{mg} / 100 \mathrm{~g}$ of feed) in female rats under our experimental conditions did not affect fecundity (pregnant females \% mated females), fertility (number of pups/litter) or pup birth weight. These results agree with the data of Tinoco et al. (1971).

Contrary to François (1983), we found no deficient female mortality at parturition. However, the diets this author used contained only $1 \%$ of sunflower oil as against $1.5 \%$ in our study and would correspond to an even lower supply of $18: 3 n-3$ and of total PUFA. 


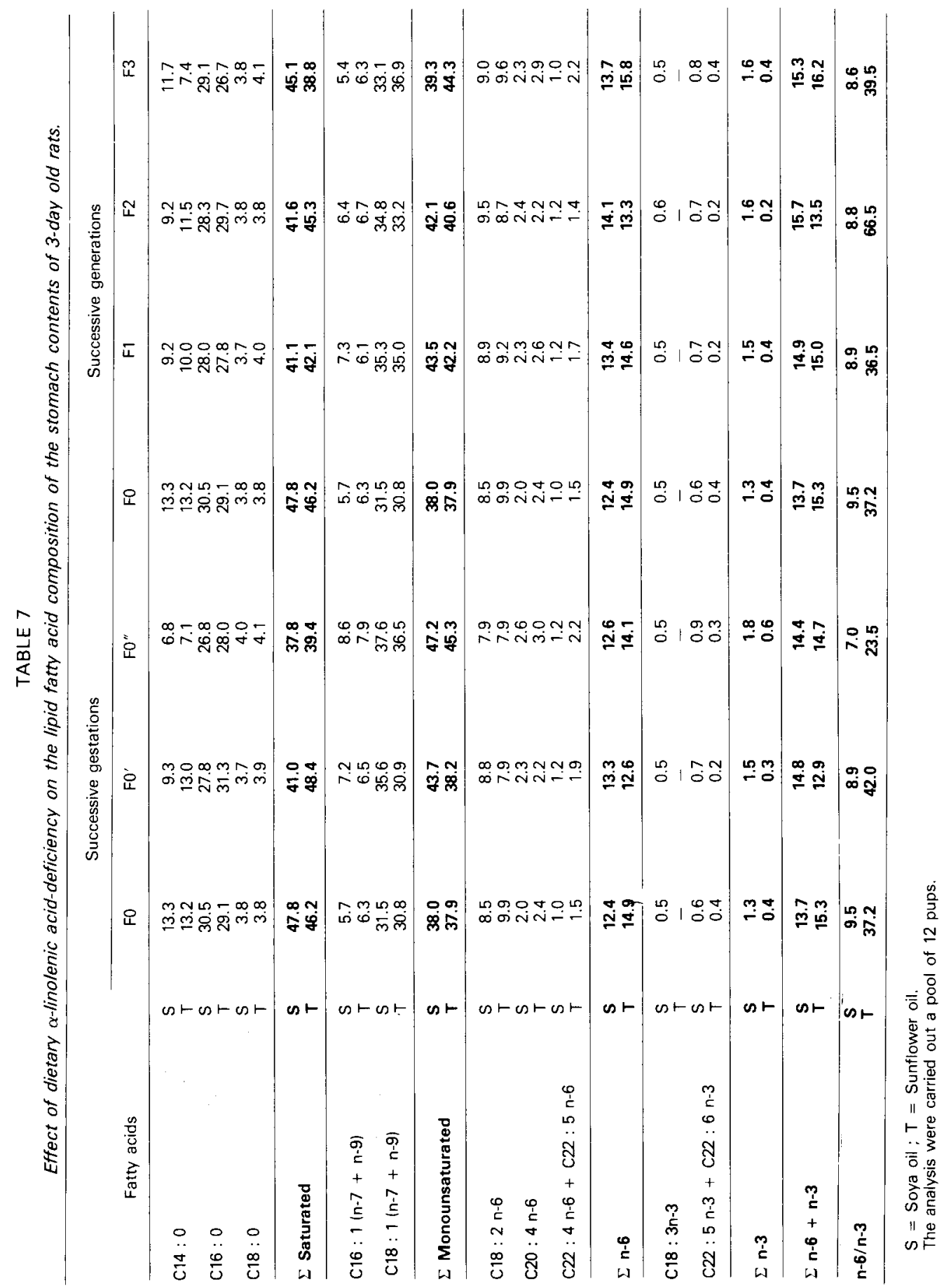


Contrary to the data of previous works (Waltman et al., 1978 ; François et al., 1980 ; François, 1983), we observed no effect on the length of gestation (22 days), which was checked during a complementary experiment in which the females were put with males for one night : parturition only lasted a shorter time ( 2 vs $3 \mathrm{~h}$ ) in " sunflower " than in " soya " dams. This could be due to the fact that $\alpha$-linolenic acid competes to inhibit the conversion of $20: 4 n-6$ into PGE 2 (Hwang and Carrol, 1980) which plays a major part in the physiology of parturition (Bergström et al., 1968).

\section{Perinatal mortality.}

$\alpha$-Linolenic acid-deficient rats showed a high perinatal mortality (14 to $24 \%$ ). This rate (the sum of stillbirths + postnatal mortality) was not reported by either Tinoco et al. (1971) or Alling et al. (1974), but was demonstrated by recent studies of François et al. (1980) and François (1983).

Stillbirth was the main cause (50 to $75 \%$ ) of perinatal mortality. In our experimental conditions, it rapidly reached a plateau (probably as early as the second generation) with successive generations but increased with successive gestations. This increase could be due to the progressive depletion of maternal stores of n-3 fatty acids.

However, since we did no cesarians, we do not know if what we termed " stillbirth " really was in utero death as described by Kummerow et al. (1952) in rats with an induced overall PUFA deficiency and/or death occurring immediately after expulsion of the foetus.

Postnatal loss did not occur beyond postpartum day 3 and was practically independent of the number of gestations and generations; it could have been caused by :

- either the neonatal respiratory distress syndrome (assuming that a sufficient amount of $n-3$ PUFA is needed to ensure the suitable metabolism of lung surfactant, a phospholipid compound which, in rats, is greatly decreased by overall PUFA deficiency : Nakamura et al., 1980);

- or by overall disfunctioning of oxidative metabolism due to the abnormal composition of the mitochondrial membranes.

\section{Postnatal growth.}

Whatever experimental design was used (successive gestations or generations), $\alpha$-linolenic acid deficiency had no effect on dietary intake and the weight profiles of the lactating mothers. This deficiency did not affect pup growth either. These results agree with the data of several authors (Tinoco et al., 1971; Alling et al., 1974 ; Tinoco et al., 1978) but not with those of Francois (1983) who observed diminished growth in deficient animals accompanied by a decrease in brain weight at weaning, changes in the electroretinogram (ERG) and behavioural disorders ; but, as mentioned earlier, the author's experimental conditions were quite different from ours.

During the 17 to 18 days following birth, the pups ingested only dam's milk. The compositions of the milks were estimated by the lipid composition of the stomach content of 3-day old pups (table 7). While the ratio of the n-3 PUFA content of both maternal diets was 22, it was only $4(1.5: 0.4)$ in the 
corresponding milks; thus, n-3 PUFA were preferentially taken up by mammary gland in the "sunflower" dams; the result is that pup n-3 PUFA deficiency during the suckling period was much less marked than a study of the maternal diet would suppose. Crawford and Sinclair (1972) reported this and noted female capacity to accumulate n-3 PUFA stores during periods of low demand and to mobilize them during period of high demand (gestation, suckling). Moreover, we expressed supplies of dietary $n-6$ and $n-3$ PUFA in absolute values, i.e. in $\mathrm{mg} / 100 \mathrm{~g}$ of feed. But it is necessary to consider the relative aspect of these fatty acid supplies as well as the quantitative aspect. We have expressed the former, as Budowski and Crawford (1985), by the ratio $n-6: n-3$. In fact, it is known that (1) the two families of $n-6$ and $n-3$ compete in various aspects of their metabolism (elongation-desaturation, eicosanoid synthesis), as mentioned in the introduction, and (2) the ratio $n-6: n-3$ in membrane lipids of land mammals varies within a narrow range, of 1 to 5 according to Budowski and Crawford (1985); as these authors note, it is preferable that the ratio not exceed 5 in dietary lipids.

In our experimental conditions, the composition of the sunflower diet, and thus of sunflower oil ( $\left.{ }^{*}\right)$ seems very unbalanced in this respect ( $\left.n-6: n-3=166.7\right)$; the corresponding composition of the milk lipids, although markedly corrected compared to that of the diet, is not satisfactory ( $n-6: n-3 \simeq 40$ ).

The value of the ratio $n-6: n-3$ is 7.2 in the soya diet lipids $v s$ a mean of 8.6 in the corresponding milk lipids. Thus, the ratio $n-6: n-3$ of the milk diet has been corrected in the opposite direction; however, the deviation between the two values was low and one could consider that a ratio value of less than 10 is preferable for the dietary lipids of nursing rats and their offsprings.

Using this observation and our results on neonatal mortality as a basis, and admitting that the $n-6$ PUFA requirement of rats in reproduction is about $1000 \mathrm{mg} / 100 \mathrm{~g}$ of feed (Pudelkewicz et al., 1968; Elmadfa et al., 1983), the $\mathrm{n}-3$ PUFA requirement of this animal would be more than $100 \mathrm{mg} / 100 \mathrm{~g}$ of feed.

It remains to be seen if the rat is a suitable model for studying n-3 PUFA requirement in mammals. The answer is not simple; most studies published on this subject have been carried out in rats and it is difficult to make comparisons. In rats, as in dogs and rabbits, testis and spermatozoa phospholipids usually contain 22 : $5 \mathrm{n}-6$ as PUFA at $22 \mathrm{C}$, while in other species as humans and bulls, the corresponding phospholipids contain $22: 6 \mathrm{n}-3$. However, these differences concern only the composition of membrane lipids in male gonads; they could be related to the temperature of these gonads, i.e. to their anatomical site (Tinoco, 1982). This particularity in $n-3$ PUFA therefore is not enough to distinguish rats from other mammals.

\section{Conclusion.}

The data of this study show that $\alpha$-linolenic acid deficiency in the diet of rats causes abnormally high perinatal mortality. These data emphasize the essential role of $n-3$ fatty acids in the reproductive function, at least in rats. 
It is surprising that the demonstration of this essential function of $n-3$ PUFA has taken so many years and has caused so much controversy. However, it was difficult to demonstrate due to several interacting factors :

a) the non-existence of dietary lipids with no traces of n-3 PUFA;

b) the presence of maternal stores meeting the demands of the foetus and newborn ;

c) moderate n-3 PUFA requirements, much lower than those of n-6 PUFA and minimized by metabolic ability to husband these fatty acids by a slow turnover (Fiesler and Anderson, 1983).

d) the ability of the organism to adapt, thus permitting some $n-6$ PUFA to be substituted for the missing $n-3$ PUFA, particularly $22: 5 n-6$ for $22: 6 n-3$ (Bourre et al., 1984).

Moreover, n-3 PUFA usually occur in tissue lipids as $\mathrm{C} 20$ and $\mathrm{C} 22$ rather than in the form of $\alpha$-linolenic acid from which they derive under the influence of desaturases. Thus, in all species in which the first of these enzymes, i.e. $\Delta 6$-desaturase, is naturally missing (Rivers $e t$ al., 1975), as well as in aging subjects in which it is less active (Peluffo and Brenner, 1974), the diet should contain $\mathrm{n}-3$ PUFA in the form of $\mathrm{C} 20$ and $\mathrm{C} 22$.

Reçu en novembre 1985. Accepté en mai 1986.

Résumé. Déficience alimentaire en acide $\alpha$-linolénique chez le rat. I. Effets sur la reproduction et la croissance post-natale.

Les effets de la déficience de l'apport alimentaire en acide $\alpha$-linolénique sur la reproduction et la croissance post-natale du rat sont étudiés au cours de 3 gestations et de 4 générations successives.

Pour ce faire, des femelles reçoivent respectivement un régime semi-synthétique dans lequel les lipides sont incorporés, soit sous forme d'huile de tournesol à raison de 1,5\% (régime carencé), soit sous forme d'huile de soja à raison de 1,87\% (régime témoin).

Les deux régimes apportent la même quantité d'acide linoléique $1940 \mathrm{mg} / 100 \mathrm{~g}$ de régime), mais le régime "Tournesol » apporte 22 fois moins d'acide $\alpha$-linolénique que le régime "Soja » (6 $\mathrm{mg}$ contre $130 \mathrm{mg} / 100 \mathrm{~g}$ de régime).

Les résultats montrent que, dans les conditions expérimentales utilisées, la déficience en acide $\alpha$-linolénique n'a pas d'influence sur la fécondité ( $\%$ de femelles gravides), la fertilité (nombre de jeunes par portée), le poids des jeunes à la naissance, la consommation alimentaire et le poids des femelles gravides ou allaitantes, la croissance des jeunes pendant I'allaitement.

En revanche, cette déficience provoque une mortalité périnatale anormalement élevée

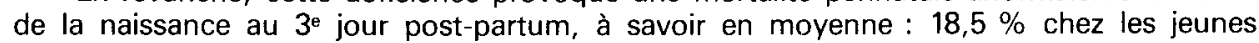
carencés, contre $5,2 \%$ chez les jeunes témoins dans le cas de gestations successives ; $16,6 \%$ chez les jeunes carencés, contre $5,3 \%$ chez les jeunes témoins dans le cas de générations successives.

Le besoin en acides gras polyinsaturés $n-3$ de la ratte en période de reproduction est discuté ; il semble se situer au-dessus de $100 \mathrm{mg} / 100 \mathrm{~g}$ d'aliment. Mais ce besoin doit être aussi estimé en fonction de l'apport en acides gras polyinsaturés $n-6$ : un rapport $n-6 / n-3$ inférieur à 10 paraît souhaitable. 


\section{References}

ALLING C., BRUCE A., KARLSSON I., SVERNERHOLM L., 1974. The effect of different levels of essential fatty acids on growth of the rat. Nut. Metab., 16, 38-50.

BERGSTRÖM S., CARLSON L. A., WEEKS J.R., 1968. The prostaglandins : a family of biologically active lipids. Pharmac. Rev., 20, 1-15.

BERNSOHN J., SPITZ F. J., 1974. Linoleic and linolenic acid dependency of some brain membranebound enzymes after lipid deprivation in rats. Biochem. Biophys. Res. Commun., 57, 293298.

BoURRE J. M., PASCAL G., DURAND G., MASSON M., DUMONT O., PICIOTTI M., 1984. Alterations in the fatty acid composition of rat brain cells (neurons, astrocytes and oligodendrocytes) and of subcellular fractions (myelin and synaptosomes) induced by a diet devoid of n-3 fatty acids. J. Neurochem., $43,342-348$.

BRECKENRIDGE W. C., MORGAN I. G., ZANETTA J. P., VINCENDON G., 1973. Adult rat brain synaptic vesicles II. Lipid composition. Biochim. biophys. Acta, 320, 681-686.

BRENNER R., PELUFFO R., 1966. Effect of saturated and unsaturated fatty acids on the desaturation in vitro of palmitic, stearic, oleic, linoleic and linolenic acids. J. biol. Chem., 241, 52135219.

BUDOWSKI P., CRAWFORD M., 1985. $\alpha$-linolenic acid as a regulator of the metabolism of arachidonic acid : dietary implications of the ratio n-6: n-3 fatty acids. Proc. Nutr. Soc., 44, 221-229.

BUDOWSKI P., HAWKEY C., CRAWFORD M., 1980. L'effet protecteur de l'acide $\alpha$-linolénique sur l'encéphalomalacie chez le Poulet. Ann. Nutr. Alim., 34, 389-400.

BURR G. O., BURR M. M., 1930. On the nature and role of the fatty acids essential in nutrition. J. biol. Chem., 86, 587-621.

CRAWFORD M., SINCLAIR A., 1972. The limitations of whole tissue analysis to define linolenic acid deficiency. J. Nutr., 102, 1315-1322.

DYERBERG J., BANG H., STOFFERSEN E., MONCADA S., VANE J., 1978. Eicosapentaenoic acid and prevention of thrombosis and atherosclerosis. Lancet, ii, 117-119.

ELMADFA I., GRUENBERG P., SCHLOTZER E., 1983. The effect of linoleic acid supply on plasma and liver lipids. Int. J. Vit. Nutr. Res., 53, 210-217.

FARNSWORTH C. C., STONE W. L., DRATZ E. A., 1979. Effects of vitamin E and selenium deficiency on the fatty acid composition of rat retinol tissues. Biochim. biophys. Acta, 552. 281-293.

FIENNES R. N., SINCLAIR A. J., CRAWFORD M. A., 1973. Essential fatty acid studies in Primates linolenic acid requirements of capuchins. J. Med. Prim., 2. 155-169.

FIESLER S. J., ANDERSON R. E., 1983. Chemistry and metabolism of lipids in the vertebra retina. Prog. Lipid Res., 22, 79-131.

FRANÇOIS M., 1983. Effets de la carence en acide $\alpha$-linolénique sur la reproduction et le développement du rat. Doct. $3^{\text {e }}$ Cycle, Université Paris VI.

FRANÇOIS M., PASCAL G., DURAND G., 1980. Effets de la carence alimentaire en acide linolénique chez le rat. Ann. Nutr. Alim., 34, 443-450.

GALLI C., MESSERI G. P., OLIVERIO A., PAOLETTI R., 1975. Deficiency of essential fatty acids during pregnancy and avoidance learning in the progeny. Pharmacol. Res. Commun., 7. $71-80$.

HOLMAN R., 1964. Nutritional and metabolic interrelationship between fatty acids. Fed. Proc., 23. 1062-1067.

HOLMAN R. T., JOHNSON S. B., HATCH T. F., 1982. A case of human linolenic acid deficiency involving neurological abnormalities. Am. J. clin. Nutr., 35, 617-623.

HWANG D. H., CARROL A. E., 1980. Decreased formation of prostaglandins derived from arachidonic acid by dietary linolenate in rats. Am. J. clin. Nutr., 33, 590-597.

JORGENSEN A. E., HOLMER G., 1969. Essential fatty acid deficient rats: growth and testes development. Lipids, 4, 301-506.

KUMMEROW F. A., PAN H. P., HICKMAN H., 1952. The effect of dietary fat on the reproductive performance and the mixed fatty acid composition of fat deficient rats. J. Nutr., 46, 489-498. 
LAMPTEY S. S., WALKER B. L., 1978. Learning behaviour and brain lipid composition in rat subjected to essential fatty acid deficiency during gestation, lactation and growth. J. Nutr., $108,358-367$.

LEAT W. M., NORTHROP C. A., 1981. Effect of linolenic acid on gestation and parturition in rat. Progr. Lipid Res., 20, 819-821.

LEE D. J., ROEHM J. N., YU T. C., SINNHUBER R. O., 1967. Effect of $\omega 3$ fatty acids on the growth rate of rainbow trout. J. Nutr., 92, 93-98.

LEMARCHAL P., 1978. Rôle biologique de l'acide linolénique. Rev. fr. Corps Gras, 6, 303-308.

MCKENZIE C. G., MCKENZIE J. B., McCOLLUM E. V., 1939. Growth and reproduction on a low fat diet. Biochemistry, 33, 935-939.

McMURCHIE E. J., RAISON J. K., 1979. Membrane lipid fluidity and its effect on the activation energy of membrane-associated enzyme. Biochim. biophys. Acta, 554, 364-374.

MOHRHAUER H., HOLMAN R. T., 1963. The effect of dose level of essential fatty acids upon fatty acid composition of the rat liver. J. Lipid Res., 4, 151-159.

NAKAMURA M., KAWAMOTA T., AKINO T., 1980. Dietary regulation of dipalmitoyl-phosphatidylcholine in the lung. Effects of essential fatty acid deficiency. Biochim. biophys. Acta, 620, 2436.

NEEDLEMAN P., RAZ A., MINKES M., FERRENDELLI J., SPRECHER H., 1979. Triene prostaglandins : prostacyclin and thromboxane biosynthesis and unique biological properties. Proc. nat. Acad. Sci. USA, 76, 944-948.

NEURINGER M., CONNOR W. E., VAN PETTEN C., BARSTAD L., 1984 . Dietary omega-3-fatty acid deficiency and visual loss in infant rhesus monkeys. J. clin. Invest., 73, 272-276.

NOUVELOT A., DEDONDER E., DEWAILLY Ph., BOURRE J. M., 1985. Influence des acides gras n-3 exogènes sur la composition en acides gras polyinsaturés de la rétine ; aspect strutural et physiologique. Cah. Nutr. Diét., XX, 123-125.

PELUFFO R., BRENNER R., 1974. Influence of dietary protein on 6 and 9-desaturation of fatty acids in rats of different ages and in different season. J. Nutr., 104, 894-900.

PUDELKEWICZ C., SEUFART J., HOLMAN R., 1968. Requirements of the female rat for linoleic and linolenic acids. J. Nutr., 94, 138-146.

QUACKENBUSH F. W., KUMMEROW F. A., STEENBACK H., 1942. The effectiveness of linoleic, arachidonic and linolenic acids on reproduction and lactation. J. Nutr., 24, 213-224.

RIVERS J. P. W., FRANKEL T. L., 1981. Essential fatty acids deficiency. Br. med. Bull., 37, 59-64.

RIVERS J., SINCLAIR A., CRAWFORD M., 1975. Inability of the cat to desaturate essential fatty acids. Nature, 258, 171-173.

SIESS W., SCHERER B., BOHLIG B., ROTH O., KURZMANN I., WEBER P., 1980 . Platelet membrane, fatty acids, platelet aggregation and thromboxane formation during a mackerel diet. Lancet, i, 441-444.

SINCLAIR H., 1981. The relative importance of essential fatty acids of the linoleic and linolenic families : studies with an eskimo diet. In R. T. HOLMAN, Progress in Lipid Research, 20, 897-899, Pergamon Press, Oxford.

SINCLAIR A. J., CRAWFORD M. A., 1972. Low fat diets and the survival of newborn rats. Biochem. J., 126, 18 P-19 P.

SINCLAIR A. J., CRAWFORD M. A., 1973. The effect of a low-fat maternal diet on neonatal rats. Br. J. Nutr., 29, 127-137.

SUN G. Y., SUN A. Y., 1974. Synaptosomal plasma membranes : acyl group composition of phosphoglycerides and $\left(\mathrm{Na}^{+} \mathrm{K}^{+}\right)$ATPase activity during fatty acid deficiency. J. Neurochem., 22, 15-19.

SVENNERHOLM L., 1968. Distribution and fatty acid composition of phosphoglycerides in normal human brain. J. Lipid Res., 9, 570-579.

TINOCO J., 1982. Dietary requirements and function of $\alpha$-linolenic acid in animal. Progr. Lipid Res., 21, 1-45.

TINOCO J., BABCOK R., HINCERBERGS I., MEDWADOVSKI B., MILGANICH P., 1978. Linolenic acid deficiency : changes in fatty acid patterns in female and male rats raised on linolenic acid deficient diet for two generations. Lipids, 13, 6-17. 
TINOCO J., WILLIAMS M. A., HINCENGERGS I., LYMAN R. L., 1971. Evidence for nonessentiality of linolenic acid in the diet of the rat. J. Nutr., 101, 937-945.

VAN DORP O. A., BEERTHUIS R. K., NUGTEREN D. H., VONKEMEAN H., 1964. The biosynthesis of prostaglandins. Biochim. biophys. Acta, 90, 204-207.

WALTMAN R., TRICOMI V., SHABANAH E. H., ARENAS R., 1978. Prolongation of rat gestation time by polyunsaturated fatty acids. Am. J. Obstet. Gynecol., 131, 735-738.

WHEELER T. G., BENOLKEN R. M., ANDERSON R. E., 1975. Visual membranes : specificity of fatty acid precursors for the electrical response to illumination. Science (Wash. D.C.), 188, $1312-1314$. 